\title{
Фокина О.А.
}

\section{Сервисная политика государства как механизм политического маркетинга}

ФАОУ ВО «Волгоградский государственный университет»

(Россия, Волгоград)

doi:10.18411/spc-01-08-2019-05

idsp: sciencepublic-01-08-2019-05

Государство как центральный, интегрирующий общество политический институт сохраняет традиционные признаки и функции, которые описаны еще в концепции М.Вебера [3; 4], однако изменяющиеся функции и механизмы их реализации на современном этапе свидетельствуют и о новом качестве государства, обновлении его сущности. Одной их особенностей глобальной политикоадминистративной реформы является стремление перестроить государственное управление по подобию маркетинга и менеджмента (менеджеризация государственного управления), реализуемого в рамках частного бизнеса, который характеризуется достаточно высоким уровнем корпоративного управления с четким распределением функциональных обязанностей на всех уровнях управления бизнесом. Также своеобразная «сервисная революция» заставила производителей товаров и услуг стремиться к предоставлению высококачественного сервиса - изменились основы конкурентной борьбы: от конкуренции ценой - к конкуренции качеством, в том числе качеством обслуживания и установления долгосрочных отношений с клиентами. Маркетинг отношений, построенный на четырех основаниях - гарантии, отзывчивость, взаимность, доверие, - стратегически направлен на установление долгосрочных взаимоотношений между производителем и потребителем, на сохранение партнеров и потребителей, что стоит гораздо меньше, чем их поиск и приобретение; именно долгосрочные отношения являются в современном обществе решающим фактором сотрудничества и конкуренции, в том числе в сфере политики.

В научной социально-политической литературе практически отсутствует понятие «сервисная политика», за исключением незначительного количества работ, посвященных развитию сервиса в РФ $[1 ; 12 ; 13]$, который рассматривается шире, чем сфера предоставления государственных услуг. Вышеуказанные авторы, а также ряд исследователей социально-экономических процессов в постиндустриальном обществе [5; 11] либо определяют сервис как социальный институт, формирующийся в условиях сервисизации различных сфер общественной жизни не только в России, но в других странах, либо прямо указывают на институциональные черты сервиса в условиях становления общества потребления.

Идея управляемости процессом предоставления социальных благ (в том числе услуг, гарантированных государством) со стороны власти содержится в ряде исследований, посвященных теории «социального государства». Для темы данной работы интересным представляются идеи Л. фон Штейна, высказанные им еще в конце XVIII в. Несмотря на то, что в его работах нет понятия «услуга», «сервисная политика», основная идея - признание и закрепление со стороны государства своих обязанностей перед гражданами - являются основанием для понимания сути сервисной политики [14; 15]. Определяя сущность социального государства и роль власти, Штейн подчеркивал, что государство обязано поддерживать социальное равенство всех граждан, «способствовать экономическому и общественному прогрессу всех своих граждан, ибо... развитие одного выступает условием развития другого» [9; с.82], и в этом заключается долженствующая функция государства. В то же в рамках теории политического маркетинга, основанной на идеях общественного договора, политический обмен голосами избирателей и услугами государства должен 
обеспечивать легитимацию власти и приводить к стремлению государства заботиться о благополучии своих граждан.

Лоренц фон Штейн, размышляя о социальной функции государства, отрицает альтруистическое начало в его деятельности: государственной власти необходимо чувствовать свою политическую защищенность, поэтому политическая стабильность достигается в служении своему народу, в обязанности заботиться о гражданах посредством реализации социальных функций - предоставление помощи от государства не в виде милостыни, а в виде социальных гарантий, обеспечения социально незащищенных граждан. Поэтому борьбу за свое существование на определенных этапах своего развития государство будет осуществлять не на языке политических идей и политического противостояния, а путем установления долгосрочных взаимоотношений государства с гражданами, направленных на обеспечение реальных интересов населения: удовлетворенные уровнем и качеством жизни, граждане не станут стремиться к радикальному изменению своего положения именно этим достигается социально-политическая стабильность. Штейн писал: «чем ничтожнее его [государства - выделено нами] граждане, тем оно само ничтожнее; чем меньше они развиты, тем менее развито само государство» [14; с.28].

Таким образом, задача любого государства - это установление сбалансированности интересов различных социально-политических акторов, и в современных условиях меняется не цель, а содержание его функций и их название. Вряд ли в ближайшем будущем достижима цель - устранение «социального неравенства, обеспечение всеобщей [выделено нами] доступности социальных благ» [14; c.28], т.к. полное совпадение интересов личности и государства вряд ли возможно. Однако исполнение государством своих функций в социальной сфере, как указывал Штейн, своеобразное «служение» обществу, «обслуживание» социальных потребностей граждан определяет политическую стабильность и снижает протестные настроения, создает условия для реализации индивидуальных потребностей и запросов.

В связи с вышесказанным политика государства приобретают новое содержание и находит отражение в следующих функциях:

1) ограничительная функция, которая проявляется в ограничении монополизации и регулировании экономики, регламентации трудовых отношений, концентрации ресурсов на социальные программы и нужды;

2) обеспечительная функция, направленная на реализацию социальных задач социальное страхование и социальное обеспечение, гарантии получения гражданам образования и услуг здравоохранения;

3) гарантирующая функция: государство на конституционном уровне гарантирует своим гражданам обеспечение системы гражданских прав, более того, государство не просто предоставляет систему государственной социальной поддержки, помощи, но становится должником своих граждан, потому что не выполнить конституционно закрепленные гарантии оно уже не может [6].

Данный вывод поддерживается основными идеями теории постиндустриального общества. Так, по мнению Д. Белла, рост благосостояния населения приведет к увеличению спроса на личные услуги, что обусловит развитие сервисного сектора, а широкое применение информационных технологий приведет и к структурным изменениям в политической сфере: утверждение плюралистической демократии будет способствовать повышению эффективности работы государственных институтов и структур [5], направленной на повышение качества сервисной политики и легитимации власти.

Применительно к самой дефиниции «сервис» в научном знании существует множество подходов его определения. Исторически сложившееся понимание сервиса как третичного сектора экономики затрудняет, на наш взгляд, понимание сути сервисной политики государства. В объяснении генезеса сервиса доминирует 
смитовская теория общественного разделения труда, согласно которой сервис возник и развивался в условиях растущей дифференциации трудовой занятости населения и выделился в отдельную сферу общественно-экономической деятельности как непроизводственный сектор [10]. Английский историк Р.М. Халтуэлл связал стремительное развитие экономики нового времени с «революцией услуг» [цит. по 11; c.41]. Согласно классической схеме стадиального развития общества К.Кларка [16], изменение профессиональной структуры общества шло по линии перераспределение трудовых кадров от первичного к вторичному и от вторичного к третичному сектору, однако важность развития третичного сектора при конструировании моделей общественного развития, как отмечает Ф. Бродель, мало кто подчеркивает. О государственном регулировании сферы предоставления услуг говорить вообще не приходится в связи с тем, что развитие данной сферы, согласно А.Смиту, происходит под влиянием «невидимой руки рынка»: есть спрос на какие-либо услуги - они появляются как доходный сегмент экономической деятельности. Задача государства в таком случае заключалась в налоговом контроле дохода лиц и предприятий, оказывающих услуги населению. Таким образом, сервис формируется исторически наряду с древнейшими формами производства, а не следует стадиально за ними.

В современном обществе без сервиса ни одна из сфер общественного бытия экономического, социального, культурного, политического - также несостоятельна. В связи с этим следует говорить о возможности и необходимости управления сервисом со стороны власти как одной из функций политического маркетинга, особенно если это касается социального благополучия граждан, на которое влияет спектр и качество оказания услуг, в том числе гарантированных государством.

При определении дефиниции «сервисная политика» малопродуктивным, на наш взгляд, является широко распространенное в политологии понимание политики М. Вебером как «стремления к участию во власти или к оказанию влияния на распределение власти, будь то между государствами, будь то внутри государства между группами людей, которые оно в себе заключает» [2; с. 646], в силу того что содержательно сервисная политика предполагает отношения между индивидами / социальными группами и государством по поводу условий их жизнедеятельности. С точки зрения социальной сущности политики, власть выступает как универсальный механизм согласования и упорядочения интеракций людей, которые реализуют собственные интересы, т.е. является механизмом интеграции интересов и запросов граждан. Следовательно, наиболее продуктивным в рамках данной работы является понимание политики как сферы отношений и деятельности, включающей в себя всё, «что обеспечивает или препятствует реализации общих интересов социальных групп и сообществ, все, что связано с человеческими ценностями: свободой, социальной справедливостью, социальным процессом» [7; с.364].

Таким образом, понятие «сервисная политика» отражает деятельность, в рамках которой государство выступает, во-первых, субъектом разработки и реализации услуг, гарантированных государством, в том числе посредством информационных и телекоммуникационных систем; во-вторых, субъектом регулирования социальноэкономических и политических взаимодействий и отношений в сфере предоставления населению социально значимых услуг, в-третьих, субъектом политических маркетинговых отношений.

Содержательно сервисная политика во многом близка социальной политике, однако не тождественна ей: социальная политика - часть сервисной политики в силу того, что реализация сервисной политики не ограничивается оказанием социально значимых услуг населению. Речь идет о консолидации ресурсов власти, бизнеса и структур гражданского общества для развития сервисной сферы как основы социального благополучия, обеспечивающей социальную справедливость и заботу о 
человеке и среде его жизнедеятельности, эффективность которой придает устойчивость общественно-политическому развитию, легитимирует правящий режим.

$$
\text { *** }
$$

1. Биндиченко Е.В. Социальные проблемы развития института сервиса в условиях трансформации российского общества. - дис. ... д-ра социол. наук. - Уфа, 2001. - 378 с.

2. Вебер М. Избранные произведения. - М.: Прогресс, 1990. - 880 с.

3. Вебер М. Политика как призвание и профессия. - М.: Изд-во: Гуманитарный центр, 2018. - 226 с. (офсет)

4. Вебер М. Хозяйство и общество: очерки понимающей социологии [Текст] : в 4 т. / Макс Вебер ; [пер. с нем.] ; сост., общ. ред. и предисл. Л. Г. Ионина; Нац. исслед. ун-т «Высшая школа экономики». - М. : Изд. дом Высшей школы экономики, 2016. - Т1. Социология. -445 с.

5. Д. Белл. Грядущее постиндустриальное общество. Опыт социального прогнозирования. - М.: Academia, 2004. - $944 \mathrm{c}$.

6. Кочеткова Л.Н. Теория социального государства Лоренца фон Штейна // Философия и общество. Выпуск № 3 (51) / 2008. [Электронный ресурс] - Режим доступа: https://www.socionauki.ru/journal/articles/130203/, открытый

7. Ледяев В. Г. Власть: концептуальный анализ. - М.: РОССПЭН, 2001. - 380 с.

8. Македонская Ж.Х. правовая природа Российской Федерации как социального государства: дис. ...канд.юр.наук. - М.: 1997. - С.57.

9. Милецкий В.П. Социальное государство: эволюция идей, сущность и перспективы становления в современной России // Политические процессы в России в сравнительном измерении. - СПб.: Издво С.-Петерб. ун-та, 1997. - С.82.

10. Смит А. Исследование о природе и причинах богатства народов. - М.: Эксмо, 2007. - (Серия: антология экономической мысли). -960 с.

11. Федулин А.А., Багдасарян В.Э. Сервис в историческом и философском осмыслении. - М.: Собрание, 2010. -240 c.

12. Фокина О.А. Институт сервиса и потребительское поведение граждан: специфика трансформации в современной России: монография. - Волгоград: Изд-во ВолГУ, 2014. - 293 с.

13. Хмелев В.В. Социальный институт сервиса в современном российском обществе: теоретикометодологические основы исследования: автреф. дис. ... д-ра социол. наук. - М., 2001. - 38 с.

14. Штейн Л. История социального движения Франции с 1789 г.: Пер. со 2 нем. изд. Т.1. / Л. Штейн Основное понятие общества и социальная история Французской революции до 1830 года. - СПБ.: Тип. А.М. Котомина, $1872 .-305$ с.

15. Штейн Л. Учение об управлении и право управления с сравнением литературы и законодательства Франции, Англии и Германии. - СПб.: Гиероглиф, 1874. - 578 с.;

16. Clark C. The Condition of Economic Progress. - London: Mc. Millan, 1940. - 212 p. 